\title{
IMPLEMENTASI PENDIDIKAN KARAKTER DISIPLIN DI SD NEGERI 7 TANJUNG RAJA
}

\author{
Welly Hartati \\ Kepala Sekolah Dasar Negeri 26 Tanjung Raja \\ e-mail:wellyhartati@gmail.com
}

\begin{abstract}
This study aimed at describing the Implementation of discipline character in SD Negeri 7 Tanjung Raja. It is a descriptive study using qualitative approach. This research was conducted at SD Negeri 7 Tanjung Raja. Data were collected through observation, interview and documentation. The validity of the data used triagulation technique which checked or compared some data, including the components of knowledge, awareness or willingness, and actions taken in implementing discipline character. This character could not succeed as long as there were no sustainability and harmony between education environments likes household and family as the first and main character formation and education environment. To improve the quality of discipline character in education, the implementation and evaluation were needed in all level of education. The results of this study showed that the discipline character in education could change the attitudes and behavior of teachers and students of SD Negeri 7 Tanjung Raja be better, for example teachers and students would shake hands when they came or left the school, finish the ceremony in turn, and dressed neatly in accordance with the appointed day, no more students who came late or skipped school. The development and implementation of discipline character was a must do action to create the students who were accustomed to behave more disciplined.
\end{abstract}

Keywords: Discipline Character, SD Negeri 7 Tanjung Raja, Behave More Disciplined.

\section{PENDAHULUAN}

Pendidikan merupakan suatu sistem yang di terapkan pada lingkungan sekolah yang teratur dan mengemban misi yang cukup antara lain: (1) Pengertian dari pendidikan luas yaitu segala sesuatu yang berkitan karakter serta apa saja yang ada dalam dengan perkembangan fisik, kesehatan, pendidikan karakter; (2) Apa pengaruh dari keterampilan, pikiran, perasaan, kemauan, pendidikan karakter; dan (3) Lemahnya sosial sampai kepada masalah kepercayaan karakter menjadikannya orang yang tidak atau keimanan. Objek yang saya ambil ini memahami akan "moral maupun akhlak". mengenai sosial yang menjadi dasar manusia Kurangnya pendidikan karakter di SD dalam mengidentifikasi kepribadian pada Negeri 7 Tanjung Raja dapat terlihat dari halmasing-masing orang tersebut. Hal ini juga hal antara lain pertama, penerapan " $5 s$ mengangkat suatu kependidikan karakter (senyum, salam, sapa, sopan, dan santun)" di yang di dalamnya terdapat moral/etika dan sekolah SD Negeri 7 Tanjung Raja akhlak yang pada saat ini telah pudar akibat belumterlaksana dengan baik dan cerminan berbagai macam masalah sosial. Berikut dari penerapan pendidikan karakter disiplin di 
sekolah belum terlasana. Tidak semua guru membuat si anak merasakan kebebasan yang telah melaksanakan karakter disiplin berkendara yang jelas hal tersebut belum di melalu pengajaran di kelas untuk setiap mata bolehkan oleh hukum. Dari kejadian ini pelajaran, dan siswa juga saat ini banyak yang seharusnya pihak orang tua lebih mengabaikan 5 s tersebut, setidaknya hanya memperhatikan anaknya dengan tidak senyum pun pada saat berpapasan dengan memberikannya fasilitas yang berlebihan juga guru terkadang siswa tidak menjalankannya dari sekolah seharusnya adanya pemberian terkecuali interaksi pada saat tatap muka di peraturan melarang untuk membawa kelas atau pada saat belajar bersama dengan kendaraan motor ke sekolah karena beresiko guru di kelas selepas itu tidak terjadi dan tidak mendidik untuk siswa dan interaksi. Setidaknya penerapan $5 \mathrm{~s}$ tersebut pengendara motor sering kebut-kebutan di dapat menciptakan interaksi yang harmonis jalan ini juga menunjukkan kurangnya antara siswa dan guru minimal agar saling disiplin.

mengenal wajah dan nama apabila Dari ketiga kasus tersebut kita dapat mempunyai daya ingat yang cukup bagus. mengetahui bahwasannya pembentukan

Kedua, kurangnya rasa hormat terhadap karakter disiplin di lingkungan sekolah ini guru yang sedang mengajar. Ketika guru merupakan hal yang penting dan memang di sedang mengajar dan menghadap papan tulis butuhkan untuk membentuk karakter disiplin sering kali ada siswa yang ngobrol tidak yang baik dalam artian seorang siswa mampu memperhatikan pada saat guru sedang bersikap saling menghargai, saling memberikan pelajaran, bahkan sering tidak menghormati, saling mengasihi kepada guru mengerjakan pekerjaan rumah. Ada juga dan antar siswa lainnya serta mempunyai diantara siswa yang tidak berpakaian rapi dan etika yang berkualitas. Diharapkan juga tidak tidak berpakaian lengkap pada saat upacara hanya pembentukan karakter yang bersifat bendera setiap hari senin.

statis namun juga dinamis agar siswa

Ketiga, sekarang ini sering terjadi kasus mengetahui dan merasakannya sendiri tentang kecelakan tragis dari Kasus ini hingga pentingnya karakter disiplin tersebut dan pada memakan korban, bahkan itidak jarang anak akhirnya seorang siswa mempunyai rasa yang masih berumur belasan tahun sudah di disiplin, rasa saling sayang yang erat kepada kasih kepercayaan oleh orang tuanya yang itu guru maupun antar siswa. Siswa-siswa jelas salah dan mirisnya dibolehkannya tersebut, dibimbing untuk temengucapkan membawa kendaraan bermotor ke sekolah Teks Pancasila dan berdoa sebelum pelajaran 
dimulai ditambah lagi diadakan yasinan Menurut penelitian di Harvard bersama setiap hari Jumat pagi, dengan University in the United States (Djalil and demikian diharapkan siswa di sekolah Megawangi, 2006), it turns out a person's khususnya siswa SDN 7 Tanjung Raja success is not determined solely by the berkarakter terupama dalam disiplin. knowledge and technical skills (hard skills),

Dalam membentuk karakter disiplin but rather by the ability to manage yang berkualitas perlu dibina sejak usia themselves and others (soft skills). Penelitian dini. Potensi karakter disiplin yang baik tersebut menyebutkan bahwa kesuksesan itu sebenarnya telah dimiliki tiap manusia determined only approximately $20 \%$ of the sebelum dilahirkan, tetapi potensi tersebut hard skills and the remaining $80 \%$ by the soft harus terus-menerus dibina melalui sosialisasi skills. Even the most successful people in the dan pendidikan sejak usia dini. Usia dini world to be successful due to the more widely merupakan masa kritis bagi pembentukan supported the ability of soft skills rather than karakter seseorang. Banyak pakar hard skills. Dari hasil penelitian tersebut mengatakan bahwa kegagalan penanaman pendidikan karakter merupakan essential for karakter disiplin sejak usia dini, akan learners improved. Seeing people of membentuk pribadi yang bermasalah dimasa Indonesia itself is also very weak in dewasanya kelak. Berangkat dari hal tersebut mastering soft skills (Kristiawan, 2015).

diatas, secara formal upaya menyiapkan Dalam pemberian pendidikan karakter kondisi, sarana/ prasarana, kegiatan, disiplin di sekolah, para pakar berbeda pendidikan, dan kurikulum yang mengarah pendapat. Setidaknya ada tiga pendapat yang kepada pembentukan watak disiplin dan budi berkembang. Pertama, bahwa pendidikan pekerti generasi muda bangsa memiliki karakter disiplin diberikan disemua mata landasan yuridis yang kuat. Namun, sinyal pelajaran. Pendapat kedua, pendidikan tersebut baru disadari ketika terjadi krisis karakter disiplin diberikan secara terintegrasi akhlak dan karakter disiplin yang menerpa dalam mata pelajaran $\mathrm{PKn}$, pendidikan semua lapisan masyarakat. Tidak terkecuali agama, dan mata pelajaran lain yang relevan. juga pada anak-anak usia sekolah. Untuk Pendapat ketiga, pendidikan karakter disiplin mencegah lebih parahnya krisis akhlak, kini terintegrasi ke dalam semua mata pelajaran. upaya tersebut mulai dirintis melalui Pendidikan karakter disiplin merupakan pendidikan karakter disiplin.

salah satu usaha yang ditempuh untuk mengatasi berbagai permasalahan bangsa 
yang sudah kompleks. Karena bangsa yang Masing-masing penamaan kadang-kadang maju bukan hanya ditinjau dari sisi ekonomi digunakan secara saling bertukaran (intertetapi dari kedisplinan, kejujuran dan exchanging) Definisi karakter Suyanto 2009 tanggung jawab. Pendidikan karakter adalah istilah karakter secara harfiah berasal dari gabungan dari dua kata, yaitu pendidikan dan bahasa latin yaitu "charakter", yang berarti : karakter. Dalam Kongres Taman Siswa Ki watak, tabiat, sifat-sifat kejiwaan, budi Hadjar Dewantara (1930) mengatakan bahwa pekerti, kepribadian atau akhlak. sebagai cara pendidikan umumnya berarti daya upaya berpikir dan berperilaku yang menjadi ciri untuk memajukan bertumbuhnya budi pekerti khas tiap individu untuk hidup dan (kekuatan batin, karakter), pikiran (intelek), bekerjasama, baik dalam lingkup keluarga, dan tubuh anak. pendidikan karakter dimulai masyarakat, bangsa dan negara. Pendidikan dari dalam keluarga, yang merupakan karakter adalah suatu usaha yang disengaja lingkungan pertama bagi pertumbuhan untuk membantu seseorang sehingga ia dapat karakter anak. Setelah keluarga, di dunia memahami, memperhatikan, dan melakukan pendidikan karakter ini sudah harus menjadi nilai-nilai etika yang inti (Lickona ,2009).

ajaran wajib sejak sekolah dasar.Anak-anak Pengertian karakter menurut Pusat adalah generasi yang akan menentukan nasib Bahasa Depdiknas adalah "bawaan, hati, jiwa, bangsa di kemudian hari. Karakter anak-anak kepribadian, budi pekerti, perilaku, yang terbentuk sejak sekarang akan sangat personalitas, sifat, tabiat, temperamen, watak" menentukan karakter bangsa di kemudian Tadkiroatun Musfiroh (UNY, 2008), hari. Karakter anak-anak akan terbentuk berkarakter adalah berkepribadian, dengan baik, jika dalam proses tumbuh berperilaku, bersifat, bertabiat, dan kembang mereka mendapatkan cukup ruang berwatak". Karakter mengacu kepada untuk mengekspresikan diri secara leluasa. serangkaian sikap (attitudes), perilaku Kirschenbaum, 2000 Pendidikan karakter (behaviors), motivasi (motivations), dan merupakan pendidikan nilai atau pendidikan keterampilan (skills).

relijius itu sendiri. pembentukan karakter Pendidikan karakter di nilai sangat peserta didik, tergantung kepada aspek penting untuk di mulai pada anak usia dini penekanannya. Di antaranya yang umum karena pendidikan karakter adalah proses dikenal ialah: Pendidikan Moral, Pendidikan pendidikan yang ditujukan untuk Nilai, Pendidikan Relijius, Pendidikan Budi mengembangkan nilai, sikap, dan perilaku Pekerti, dan Pendidikan Karakter itu sendiri. yang memancarkan akhlak mulia atau budi 
pekerti luhur. Nilai-nilai positif dan yang

Pendidikan karakter adalah suatu sistem seharusnya dimiliki seseorang menurut ajaran penanaman nilai-nilai karakter kepada warga budi pekerti yang luhur adalah amal saleh, sekolah yang meliputi komponen amanah, antisipatif, baik sangka, bekerja pengetahuan, kesadaran atau kemauan, dan keras, beradab, berani berbuat benar, berani tindakan untuk melaksanakan nilai-nilai memikul resiko, berdisiplin, berhati lapang, tersebut. Dalam pendidikan karakter disiplin berhati lembut, beriman dan bertaqwa, di sekolah, semua komponen (pemangku berinisiatif, berkemauan keras, pendidikan) harus dilibatkan, termasuk berkepribadian, berpikiran jauh ke depan, komponen-komponen pendidikan itu sendiri, bersahaja, bersemangat, bersifat konstruktif, yaitu isi kurikulum, proses pembelajaran dan bersyukur, bertanggung jawab, bertenggang penilaian, penanganan atau pengelolaan mata rasa, bijaksana, cerdas, cermat, demokratis, pelajaran, pengelolaan sekolah, pelaksanaan dinamis, efisien, empati, gigih, hemat, ikhlas, aktivitas atau kegiatan ko-kurikuler, jujur, kesatria, komitmen, kooperatif, pemberdayaan sarana prasarana, pembiayaan, kosmopolitan (mendunia), kreatif, kukuh hati, dan etos kerja seluruh warga lugas, mandiri, manusiawi, mawas diri, sekolah/lingkungan.

mencintai ilmu, menghargai karya orang lain, Dengan demikian, pendidikan karakter menghargai kesehatan, menghargai pendapat dimaknai sebagai suatu perilaku warga orang lain, menghargai waktu, patriotik, sekolah yang dalam menyelenggarakan pemaaf, pemurah, pengabdian, pendidikan harus berkarakter. pendidikan berpengendalian diri, produktif, rajin, ramah, karakter merupakan upaya yang harus rasa indah, rasa kasih sayang, rasa melibatkan semua kepentingan dalam keterikatan, rasa malu, rasa memiliki, rasa pendidikan, baik pihak keluarga, sekolah, percaya diri, rela berkorban, rendah hati, lingkungan sekolah, dan juga masyarakat sabar, semangat kebersamaan, setia, siap luas. Karena itu langkah awal yang perlu mental, sikap adil, sikap hormat, sikap nalar, dilakukan adalah membangun kembali sikap tertib, sopan santun, sportif, susila, taat kemitraan dan jejaring pendidikan yang asas, takut bersalah, tangguh, tawakal, tegar, kelihatannya mulai terputus antara tegas, tekun, tepat janji, terbuka, ulet, dan lingkungan sekolah yaitu guru, keluarga, dan sejenisnya. Seharusnya pendidikan karakter masyarakat.

ini memang sangat penting dimulai sejak dini. Pembentukan dan pendidikan karakter tidak akan berhasil selama antara lingkungan 
pendidikan tidak ada kesinambungan dan bangsa; 4) mengembangkan kemampuan keharmonisan. Dimulai dari, rumah tangga peserta didik menjadi manusia yang mandiri, dan keluarga sebagai lingkungan kreatif dan berwawasan kebangsaan; 5) pembentukan dan pendidikan karakter mengembangkan lingkungan kehidupan pertama dan utama harus lebih diberdayakan sekolah sebagai lingkungan belajar yang yang kemudian didukung oleh lingkungan aman, jujur, penuh kreativitas dan dan kondisi pembelajaran di sekolah yang persahabatan, serta rasa kebangsaan yang memperkuat proses pembentukan tersebut. tinggi dan penuh kekuatan.

Pendidikan karakter bertujuan untuk Peran Guru Dalam Pengembangan meningkatkan mutu penyelenggaraan dan Pendidikan Karakter, Guru merupakan sosok hasil pendidikan di sekolah yang mengarah yang bisa ditiru atau menjadi idola bagi pada pencapaian pembentukan karakter dan peserta didik. Guru bisa menjadi sumber akhlak mulia peserta didik secara utuh, inpirasi dan motivasi peserta didiknya. Dalam terpadu, seimbang, dan sesuai dengan standar pengembangan karakter peserta didik di kompetensi lulusan. Melalui pendidikan sekolah, guru memiliki posisi yang strategis karakter diharapkan peserta didik mampu sebagai pelaku utama. Sikap dan prilaku secara mandiri meningkatkan dan seorang guru sangat membekas dalam diri menggunakan pengetahuannya dalam siswa. Sehingga ucapan, karakter dan mempersonalisasi nilai-nilai karakter dan kepribadian guru menjadi cermin siswa. Ada akhlak mulia sehingga terwujud dalam beberapa strategi yang dapat memberikan perilaku sehari-hari (Kristiawan, 2016). peluang dan kesempatan bagi guru untuk

Tujuan pendidikan karakter menurut memainkan peranannya secara optimal dalam Puskur (2010) yaitu 1) mengembangkan hal pengembangan pendidikan karakter potensi kalbu/nurani/afektif peserta didik peserta didik di sekolah, sebagai berikut sebagai manusia dan warga negara yang 1)Guru dalam proses pembelajaran, memiliki nilai-nilai budaya dan karakter seyogyanya berperan sebagai sutradara yang bangsa; 2) Mengembangkan kebiasaan dan mengarahkan, membimbing, memfasilitasi perilaku peserta didik yang terpuji dan sejalan dalam proses pembelajaran, sehingga peserta dengan nilai-nilai universal dan tradisi didik dapat melakukan dan menemukan budaya bangsa yang religius; 3) menanamkan sendiri hasil belajarnya perannya sebagai jiwa kepemimpinan dan tanggung jawab optimalisasi. 2) Guru dituntut untuk perduli, peserta didik sebagai generasi penerus mau dan mampu mengaitkan konsep-konsep 
pendidikan karakter pada materi-materi dalam pengembangan potensi peserta didik pembelajaran dalam mata pelajaran yang yang lebih bermartabat; dan 3) Penyaring diampunya, yang dapat diintergrasikan dalam yaitu untuk menyaring budaya bangsa sendiri proses pembelajaran. Integrasi materi dan budaya bangsa lain yang tidak sesuai pendidikan karakter ke dalam mata pelajaran dengan nilai budaya dan karakter budaya 3) Guru melalui program pembiasaan diri yang bermartabat. Fungsi pendidikan karakter lebih mengedepankan atau menekankan yaitu menumbuh kembangkan kemampuan kepada kegiatan-kegiatan pengembangan dasar peserta didik agar berpikir cerdas, budi pekerti dan akhlak mulia yang berperilaku yang berakhlak, bermoral, dan kontekstual, kegiatan yang menjurus pada berbuat sesuatu yang baik, yang bermanfaat pengembangan kemampuan afektif dan bagi diri sendiri, keluarga dan masyarakat.

psikomotorik; 4) Guru mampu menciptaan

Dengan demikian berdasarkan paparan lingkungan sekolah yang kondusif untuk di atas, dapat disimpulkan bahwa guru tumbuh dan berkembangnya karakter peserta sebagai pengajar dan pendidik, yang berarti didik, baik lingkungan fisik maupun disamping mentransfer ilmu pengetahuan, lingkungan spiritual; 5) Menjalin kerjasama juga mendidik dan mengembangkan dengan orang tua peserta didik dan kepribadian peserta didik melalui intraksi masyarakat dalam pengembangan pendidikan yang dilakukannya di kelas dan luar kelas. karakter sebagai fasilitator dan nara sumber Guru harus memberikan rasa aman dan dalam kegiatan-kegiatan pengembangan keselamatan kepada setiap peserta didik di pendidikan karakter yang dilaksanakan di dalam menjalani masa-masa belajarnya. sekolah; 6) Menjadi figur teladan bagi peserta tentang peranan guru di sekolah, keluarga dan didik. Dalam proses pembelajaran, intergrasi masyarakat di pandang dari segi dirinilai-nilai karakter tidak hanya dapat pribadinya (self oriented), seorang guru harus diintegrasikan ke dalam subtansi atau materi berperan sebagai 1) pekerja sosial, yaitu pelajaran, tetapi juga pada prosesnya. seorang yang harus memberikan pelayanan

Fungsi dari pendidikan karakter dan kepada masyarakat; 2) pelajar dan ilmuwan, budaya bangsa menurut Puskur (2010) adalah yaitu seorang yang harus senantiasa belajar 1) pengembangan potensi peserta didik untuk secara terus menerus untuk mengembangkan menjadi pribadi yang berperilaku baik; 2) penguasaan keilmuannya; 3) orang tua, perbaikan yaitu memperkuat kiprah artinya guru adalah wakil orang tua peserta pendidikan nasional untuk bertanggung jawab didik bagi setiap peserta didik di sekolah; 
4) model keteladanan, artinya guru adalah benda serta rekaman gambar (Sutopo, 2002: model perilaku yang harus dicontoh oleh para 64) yaitu melakukan pengamatan ke lokasi peserta didik; 5) pemberi keselamatan bagi penelitian di SD Negeri 7 Tanjung Raja. setiap peserta didik. Peserta didik diharapkan Adapun yang di observasi adalah akan merasa aman berada dalam didikan implementasi pendidikan karakter disiplin. gurunya.Untuk meningkatkan kesesuaian dan Berikutnya adalah wawancara yang dilakukan mutu pendidikan karakter, Kemdiknas dengan cara mengadakan komunikasi mengembangkan grand design pendidikan langsung dengan pihak-pihak yang dapat karakter untuk setiap jalur, jenjang, dan jenis mendukung diperolehnya data yang berkaitan satuan pendidikan. Grand design menjadi dengan permasalahan yang diteliti. Teknik rujukan konseptual dan operasional wawancara yang digunakan dalam penelitian pengembangan, pelaksanaan, dan penilaian ini adalah teknik wawancara tidak terstruktur. pada setiap jalur dan jenjang Dengan demikian wawancara dilakukan pendidikan. Pengembangan dan implementasi dengan pertanyaan yang bersifat "openpendidikan karakter perlu dilakukan dengan ended", dan mengarah kepada kedalaman mengacu pada grand design tersebut. informasi (Sutopo, 2002: 59) dari data primer. Konfigurasi karakter dalam konteks totalitas Peneliti melakukan wawancara dengan proses psikologis dan sosial-kultural tersebut mengajukan pertanyaan untuk memperoleh dikelompokan menjadi 1) olah hati (spiritual informasi yang berkaitan dengan desain and emotional development); 2) olah pendidikan karekter disiplin.

pikir (intellectual development); 3) olah raga Selanjutnya studi dokumen sebagai data dan kinestetik (physical and kinestetic tambahan (sekunder), akan tetapi data ini development); 4) olah rasa dan karsa berfungsi memperjelas dan melengkapi data (affective and creativity development). utama. Studi dokumen dilakukan dengan

\section{METODE PENELITIAN}

Penelitian ini menggunakan metode karakter disiplin pada SD Negeri 7 Tanjung penelitian kualitatif etnografi. Dalam Raja. Terakhir peneliti menggunakan penelitian ini peneliti menggunakan teknik triangulasi sebagai teknik pengumpulan data pengumpulan data observasi yang digunakan yang bersifat menggabungkan dari berbagai untuk menggali data dari sumber data yang teknik pengumpulan data dan sumber data berupa peristiwa, tempat atau lokasi dan yang telah ada. Bila peneliti melakukan 
pengumpulan data dengan triangulasi, maka

SD Negeri 7 Tanjung Raja tidak sebenarnya peneliti mengumpulkan data yang sekedar membentuk siswa menjadi pribadi sekaligus menguji kredibilitas data. Pengujian yang cerdas dan baik, melainkan juga itu dilakukan dengan mengecek kredibilitas membentuk mereka menjadi pelaku baik bagi data dengan berbagai teknik pengumpulan perubahan dalam hidupnya sendiri, yang pada data dan sumber data (Sugiyono, 2007: 83). gilirannya akan menyumbangkan perubahan dalam tatanan sosial kemasyarakatan menjadi

\section{HASIL PENELITIAN DAN}

PEMBAHASAN

Pembelajaran SD Negeri 7 Tanjung proses pembelajaran, diskusi, dan mengambil Raja berbasis pendidikan karakter disiplin inisiatif sebagai upaya membangun dalam hal: 1) menerapkan disiplin dalam pendidikan karakter. Kemudian mereka juga segala kegiatan dengan menjadikan guru dan bertanggungjawab untuk menjadi model yang pengelola satuan pendidikan sebagai teladan; memiliki nilai-nilai moral dan memanfaatkan 2) membudayakan 5s (senyum, salam, sapa, kesempatan untuk mempengaruhi siswasopan, dan santun) dalam hubungan siswanya. Artinya pendidikan karakter antarwarga sekolah sehingga timbul disiplin di lingkungan SD Negeri 7 Tanjung keakraban; 3) menumbuhkan penghayatan Raja hendaklah mampu dan pengamalan ajaran agama dan budaya mengimplementasikan pendidikan karakter sehingga menjadi sumber kearifan dalam disiplin dalam pendidikan di SD Negeri 7 bertindak; 4) mengoptimalkan pelaksanaan Tanjung Raja (Hasil wawancara dengan pembelajaran secara efektif saling membantu kepala sekolah, 31 Oktober 2017).

dalam mencegah kekosongan jam pelajaran $\quad$ SD $\quad$ Negeri 7 Tanjung Raja sehingga setiap peserta didik tidak mengimplementasikan pendidikan karakter terbengkalai dalam menerima pembelajaran; disiplin adalah melalui Pendekatan Holistik, 5) melaksanaan evaluasi proses dan hasil yaitu mengintegrasikan perkembangan belajar secara konsisten, transparan, dan karakter ke dalam setiap aspek kehidupan melaksanaan program perbaikan dan sekolah, 1) segala sesuatu di sekolah diatur pengayaan; 6) membantu peserta didik untuk berdasarkan perkembangan hubungan antara mengenali potensi dirinya (Hasil wawancara siswa, guru, dan masyarakat; 2) sekolah dengan kepala sekolah, 31 Oktober 2017)

merupakan masyarakat peserta didik yang peduli di mana ada ikatan yang jelas yang 
menghubungkan siswa, guru, dan sekolah; 3) sekolah. Sekolah memiliki program pembelajaran emosional dan sosial setara ekstrakurikuler Pramuka, olahraga, Dalam dengan pembelajaran akademik; 4) kerja rangka menguatkan karakter religius, setiap sama dan kolaborasi di antara siswa menjadi pagi Jumat anak-anak yasinan bersama pada hal yang lebih utama dibandingkan pukul 07.10 dipandu oleh petugas yang telah persaingan; 5) nilai-nilai seperti keadilan, rasa ditunjuk secara bergantian untuk setiap kelas. hormat, dan kejujuran menjadi bagian memberikan pelayanan; 7) disiplin dan pembelajaran sehari-hari baik di dalam pengelolaan kelas menjadi fokus dalam maupun di luar kelas; 6) siswa-siswa memecahkan masalah dibandingkan hadiah diberikan banyak kesempatan untuk dan hukuman; dan 8) model pembelajaran mempraktekkan prilaku moralnya melalui yang berpusat pada guru harus ditinggalkan kegiatan-kegiatan seperti pembelajaran dan beralih ke kelas demokrasi di mana guru sekolah, guru, orang tua dan masyarakat dan siswa berkumpul untuk membangun untuk menjadi model prilaku sosial dan kesatuan, norma, dan memecahkan masalah moral.

(Hasil wawancacara kepala sekolah, 31

Strategi yang dilakukan SD Negeri 7 Oktober 2017).

Tanjung Raja dalam pembelajaran karakter Sementara itu peran SD Negeri 7 dan menjaga mutu lulusan adalah membentuk Tanjung Raja dalam mengimplementasikan budaya sekolah, yaitu perilaku, tradisi, penguatan pendidikan karakter mencakup 1) kebiasaan keseharian, dan simbol-simbol mengumpulkan guru, orang tua dan siswa yang dipraktikkan oleh semua warga sekolah, bersama-sama mengidentifikasi dan dan masyarakat sekitar sekolah. Hasil mendefinisikan unsur-unsur karakter yang penelitian ini didukung oleh penelitian mereka ingin tekankan, 2) memberikan Ahmad dkk (2017) dalam pembelajaran pelatihan bagi guru tentang bagaimana karakter adalah membentuk budaya sekolah, mengintegrasikan penguatan pendidikan yaitu perilaku, tradisi, kebiasaan keseharian, karakter ke dalam kehidupan dan budaya dan simbol-simbol yang dipraktikkan oleh sekolah, 3) menjalin kerja sama dengan semua warga sekolah, dan masyarakat sekitar orangtua dan masyarakat agar siswa dapat sekolah. Mengimplementasikan pembelajaran mendengar bahwa prilaku karakter itu penting karakter adalah melalui Pendekatan Holistik, untuk keberhasilan di sekolah dan di yaitu mengintegrasikan perkembangan kehidupannya, dan 4) memberikan karakter ke dalam setiap aspek kehidupan kesempatan kepada kepala Kemudian untuk 
menumbuhkembangkan karakter peduli berkembang ke berikutnya. Hasil penelitian sosial, jika ada yang sakit seluruh siswa ini menunjukkan bahwa Pendidikan karakter diminta mengumpulkan sumbangan. disiplin dapat merubah sikap dan tingkah laku

Untuk karakter tanggung jawab, jika guru maupun siswa-siswa SD Negeri 7 ada yang ngepek saat ulangan diberikan Tanjung Raja kearah yang lebih baik, sesuai sanksi yang berat yaitu keliling kelas, sambil dengan yang di harapkan untuk semua warga mengucapkan "maaf saya ketahuan ngepek, sekolah seperti sudah ditunjukkannya bila tolong jangan ikuti saya”. Untuk membentuk datang dan pulang sekolah saling bersalaman, karakter nasionalis yaitu saat upacara betul- dan bila selesai upacara siswa secara betul disiplin tidak boleh mundur dari bergiliran bersalaman dengan guru dan juga barisan. Kemudian untuk menumbuhkan berpakaian rapi sesuai dengan hari yang telah karakter disiplin pada waktu awal masuk ditentukan, tidak ada lagi siswa yang datang diadakan pelatihan kedisiplinan selama 3 terlambat dan sering bolos sekolah. (tiga) hari yang dibina oleh guru-guru Dalam Pengembangan dan implementasi pendidikan rangka menumbuhkan karakter berbudi karakter disiplin perlu dilakukan dengan pekerti luhur, apabila ada yang menemukan mengacu pada implementasi pendidikan uang siswa langsung diminta karakter untuk penerapkan pendidikan memberitahukan kepada guru piket dan karakter disiplin sejak dini, diharapkan siswa kemudian diumumkan. Kemudian untuk sampai dewasa sudah terbiasa untuk karakter saling hormat menghormati, jika berprilaku disiplin.

bertemu dengan guru para siswa bersalaman

baik di dalam maupun di luar kelas. Antara KESIMPULAN

kakak tingkat dan adik tingkat tidak ada Hasil penelitian Pembelajaran SD istilah senior junior, mereka (Kristiawan, Negeri 7 Tanjung Raja implementasi 2016). Proses pembentukan dimulai dari pendidikan karakter disiplin dalam penguatan pengenalan perilaku baik dan buruk dan pendidikan adalah religius, berbudi pekerti pembiasaan perilaku baik dalam kehidupan luhur, berdaya bertaqwa terhadap Tuhan sehari-hari. Pada usia pra sekolah, pendidikan Yang Maha Esa. Hal tersebut dilakukan karakter efektif dilakukan oleh keluarga. dengan cara 1) menerapkan disiplin dalam Lebih lanjut Sudirman (1985:63-65) segala kegiatan dengan menjadikan guru dan menyebutkan masa inilah penentuan pengelola satuan pendidikan sebagai teladan; pembentukan karakter anak untuk dasar 2) membudayakan $5 \mathrm{~s}$ (senyum, salam, sapa, 
sopan, dan santun) dalam hubungan bahwa ada perubahan sikap yang positif dari antarwarga sekolah sehingga timbul siswa SD Negeri 7 Tanjung Raja setelah keakraban 3) menumbuhkan penghayatan dan diterapkannya pendidikan karakter disiplin, pengamalan ajaran agama dan budaya yaitupada saat berpapasan dengan guru siswa sehingga menjadi sumber kearifan dalam menerapkan 5s (senyum, sapa, salam, sopan bertindak; 4) mengoptimalkan pelaksanaan dan santun), hormat terhadap guru yang pembelajaran secara efektif saling membantu sedang mengajar, berpakaian rapi dan sudah dalam mencegah kekosongan jam pelajaran membuang sampah pada tempatnya. Hasil sehingga setiap peserta didik tidak penelitian ini menunjukkan bahwa terbengkalai dalam menerima pembelajaran; Pendidikan karakter disiplin dapat merubah 5) melaksanaan evaluasi proses dan hasil sikap dan tingkah laku guru maupun siswabelajar secara konsisten, transparan, dan siswa SD Negeri 7 Tanjung Raja kearah yang melaksanaan program perbaikan dan lebih baik, sesuai dengan yang di harapkan pengayaan; 6) membantu peserta didik untuk untuk semua warga sekolah seperti sudah mengenali potensi dirinya; 7) memotivasi dan ditunjukkannya bila datang dan pulang membantu peserta didik untuk mengenali sekolah saling bersalaman, dan bila selesai potensi dirinya dengan memberikan wadah upacara siswa secara bergiliran bersalaman dalam kegiatan ekstrakurikuler, sehingga dengan guru dan juga berpakaian rapi sesuai setiap peseta didik dapat berkembang secara dengan hari yang telah ditentukan, tidak ada optimal; 8) membiasakan gemar membaca; 9) lagi siswa yang datang terlambat dan sering menerapkan penggunaan bahasa Indonesi bolos sekolah. Pengembangan dan dalam komunikasi antarwarga sekolah; 10) implementasi pendidikan karakter disiplin mengoptimalkan pelaksanaan $9 \mathrm{~K}$ dengan perlu dilakukan dengan mengacu memberdayakan potensi yang ada di pada implementasi pendidikan karakter untuk lingkungan sekolah; 11) memupuk rasa penerapkan pendidikan karakter disiplin sejak kepedulian sosial terhadap teman yang dini, diharapkan siswa sampai dewasa sudah mendapat musibah, 12) melaksanakan terbiasa untuk berprilaku disiplin. yasinan bersama dan memberi infak setiap hari Jumat.

\section{DAFTAR PUSTAKA}

Dalam pembinaan perkembangan psikis pada masa kecil meliputi: perasaan, kemauan, Suhono, S. (2017). Desain dan cipta. Hasil penelitian ini menyebutkan Pembelajaran SMA Plus Negeri 2 Banyuasin III Berbasis Karakter Di Era 
Masyarakat Ekonomi ASEAN. Iqra

(Educational Journal), 2(2), 403-432.

Alfabeta. Munir, Abdullah. (2010). Pendidikan Karakter, Yogyakarta: Pedagogia

Djalil, S. A. and Megawangi, R. (2006). Upgrading the educational quality at Aceh through the model of educational holistic based character. Scientific Oration on Dies Natalis 45 Syiah Kuala University Banda Aceh

Gunawan, Heri. (2012).Pendidikan Karakter (Konsep dan Implementasi) Bandung:

Kristiawan, M. (2015). A Model of Educational Character in High School Al-Istiqamah Simpang Empat, West Pasaman, West Sumatera. Research Journal of Education, 1(2), 15-20.

Kristiawan, M. (2016). Telaah Revolusi Mental dan Pendidikan Karakter dalam Pembentukkan Sumber Daya Manusia Indonesia yang Pandai dan Berakhlak Mulia. Ta'dib, 18(1), 13-25

Megawangi, Ratna. (2004). Pendidikan Karakter. Jakarta: Indonesia Heritage Fondation.

Mulyana. (2003). Kurikulum Berbasis Kompetensi. Bandung: Remaja Rosdakarya. N.

Munib, Achmad, dkk. (2012). Pengantar Ilmu Pendidikan. Semarang: Pusat Pengembangan MKU/MKDK-LP3 Universitas Negeri Semarang.

Sudirman. (1992). Ilmu pendidikan, Bandung: Remaja Rosdakarya

Tirtarahardja, Umar, dkk. (2008). Pengantar Ilmu Pendidikan. Jakarta: PT Rineka Cipta. 